\title{
Precipitation and temperature regime over Cyprus as a result of global climate change
}

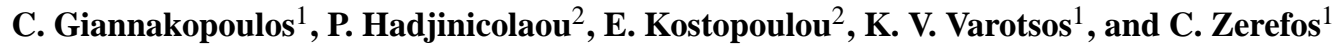 \\ ${ }^{1}$ Institute for Environmental Research and Sustainable Development, National Observatory of Athens, Athens, Greece \\ ${ }^{2}$ Energy Environment Water Research Center, The Cyprus Institute, Nicosia, Cyprus
}

Received: 24 March 2009 - Revised: 18 December 2009 - Accepted: 21 December 2009 - Published: 19 February 2010

\begin{abstract}
In this study, the impact of global climate change on the temperature and precipitation regime over the island of Cyprus has been investigated. The analysis is based on daily output from a regional climate model (RCM) at a high horizontal resolution $(25 \mathrm{~km})$ produced within the framework of the EU-funded ENSEMBLES project. The control run represents the base period 1961-1990 and is used here as reference for comparison with future predictions. Two future periods are studied, 2021-2050 and 2071-2100. For the study area and over the study period, an analysis of the changes associated with the temperature regime and the hydrological cycle, such as mean precipitation and drought duration, is presented. Variations in the mean annual and seasonal rainfall are presented. Changes in the number of hot days/warm nights as well as drought duration are also discussed. These changes should be very important to assess future possible water shortages over the island and to provide a basis for associated impacts on the agricultural sector.
\end{abstract}

\section{Introduction}

The Intergovernmental Panel on Climate Change Fourth Assessment Report (IPCC-AR4) indicates significant summer warming in south-eastern Europe and the Mediterranean, while downward trends are associated with the mean annual precipitation (Christensen et al., 2007). The combined effect of high temperatures and low rainfall poses challenges to many economic sectors as well as a significant threat of desertification (Giorgi, 2006; Gao and Giorgi, 2008). For instance, the IPCC-AR4 highlights that water stress will increase in southern Europe, and hence agriculture will have to cope with increasing water demand for irrigation (Alcamo

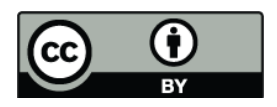

Correspondence to: C. Giannakopoulos (cgiannak@meteo.noa.gr) et al., 2007). In addition, the observed climate changes are likely to enhance the frequency and intensity of extreme events' occurence, such as heatwaves and droughts (Gao et al., 2006; Meehl et al., 2007) which may critically affect the society and economy of small island countries, like Cyprus. There is therefore a need for more accurate climate model predictions that will provide meteorological information on national level and enable relevant climate change impact studies to assist adaptation strategies. A wealth of data for the future state of the climate is now becoming available for Europe from state-of-the-art, high-resolution, climate model simulations, that allow estimates for future climate extremes and their impacts on a regional level (Déqué et al., 2005; Hewitt, 2005; Christensen and Christensen, 2007; Déqué et al., 2007).

Cyprus lies at the eastern end of the Mediterranean Sea, hence it belongs in the Mediterranean climate zone and therefore, experiences mild winters and hot dry summers. Winters are mild, with some rain and snow on Troodos mountains. In summer, the extension of the summer Asian Thermal Low is evident throughout the eastern Mediterranean in all seasonal circulation patterns (Kostopoulou and Jones, 2007a, b), associated with high temperatures and abundant sunshine. The average daytime temperature in winter ranges from $12-15^{\circ} \mathrm{C}$. In summer, the average maximum temperature in coastal regions is $32^{\circ} \mathrm{C}$. Further inland, the maximum temperature often reaches $40^{\circ} \mathrm{C}$. The wet season extends from November to March, with most (approx. 60\%) of the rain falling between December and February (Pashiardis, 2002). Precipitation is generally associated with the movement of moist maritime flows to the North, occurring particularly over areas of high elevation (Kostopoulou and Jones, 2007a). Winter precipitation is closely related to cyclogenesis in the region (Pinto et al., 2001). Nevertheless, it is not uncommon for isolated summer thunderstorms to occur, which however contribute to less than $5 \%$ to the total annual precipitation amount (Pashiardis, 2002). The characteristic

Published by Copernicus Publications on behalf of the European Geosciences Union. 
Table 1. Station details.

\begin{tabular}{llcc}
\hline Station & Lat $\left({ }^{\circ} \mathrm{N}\right)$ & Lon $\left({ }^{\circ} \mathrm{E}\right)$ & $\begin{array}{c}\text { Altitude }(\mathrm{m} \\
\text { above mean sea level })\end{array}$ \\
\hline Nicosia & 35.16 & 33.35 & 160 \\
Larnaca & 34.88 & 33.63 & 2 \\
Limassol & 34.66 & 33.02 & 31 \\
Prodromos & 34.95 & 32.83 & 1423 \\
Stavros & 35.02 & 32.63 & 810 \\
Amiantos & 34.93 & 32.92 & 1397 \\
Lefkara & 34.9 & 33.29 & 391 \\
Saittas & 34.86 & 32.91 & 641 \\
Panagia & 34.92 & 32.63 & 871 \\
\hline
\end{tabular}

summer aridity of the region has significant implications in several socio-economic sectors. Cyprus is facing its worst ever water shortage in the last few decades.

Climate models are widely used to project present and future changes of climate variables. Although the ability of models has improved, systematic biases can be found in model simulations. Therefore it is recommended the accuracy of model simulations of past or contemporary climate to be evaluated by comparing the results with observations. In this study, a high resolution Regional Climate Model (RCM) was utilised to examine changes and variations in precipitation over Cyprus. In addition, observational temperature and precipitation data from meteorological stations on the island were used to evaluate the model accuracy. Finally, projected temperature and precipitation for the periods of the near (2021-2050) and far (2071-2100) future are presented as changes from the recent past (1961-1990) for both mean and extreme parameters.

\section{Model and data}

Daily output data, from the RACMO2 regional climate model, developed at KNMI in the Netherlands (Lenderink et al., 2007), from runs performed in the framework of the ENSEMBLES project (www.ensembles-eu.org) were used. RACMO2 has 40 vertical levels in a hybrid sigma-pressure following coordinate system. The horizontal resolution is $25 \mathrm{~km} \times 25 \mathrm{~km}$, which produces a European-Mediterranean grid of $85^{\circ}$ longitude $\times 95^{\circ}$ latitude grid cells in a rotated latitude-longitude projection. The model uses initial and boundary conditions from the General Circulation Model (GCM) ECHAM5. The high spatial resolution of RACMO2 enables a satisfactory representation of the island. The control run represents the base period 1961-1990 and is used here as reference for comparison with future projections for the periods 2021-2050 and 2071-2100. The future period simulations of the model, 2021-2050 and 2071-2100 are based on the IPCC SRES A1B scenario. The A1B scenario provides a good mid-line scenario for carbon dioxide emissions and economic growth (Alcamo et al., 2007).

The observational data obtained from the Cyprus Meteorological Sevice archives are daily weather records available from 1976 to present. The stations are located at various geographic locations and altitudes to represent the complex terrain of the island. Table 1 provides a list of the latitude/longitude co-ordinates and elevation of each station. It is evident from Table 1, that some are coastal stations, while others are continental at low, medium or high altitudes.

\section{Evaluation of the recent past}

The years 1961-1990 were used as reference period to examine potential future changes in the temperature and precipitation regime in Cyprus for two 30-year future periods 2021-2050 and 2071-2100. However, before presenting the findings of the study, it is important to briefly discuss the results of the model evaluation analysis.

Due to the late start of the observational data records, the common evaluation period of data had to be reduced to 13 years, covering the period 1977-1990. The selection of the model data, used for the evaluation, was based on extracting the four nearest RCM grid point to each observation location. The closest land grid point was found to be the most representative for each site. The mean daily minimum $\left(T_{\min }\right)$, maximum $\left(T_{\max }\right)$ temperatures and precipitation (RR) for each calendar-day over the evaluation period were calculated to illustrate their seasonal cycles, as represented by both model and observational datasets. Figure 1, shows some representative examples of the reproduced annual cycle of maximum (left panels), minimum (middle panels) temperature and precipitation (right panels) for three selected stations. In general, the model captures well the seasonal variability of temperature, in most stations. In particular, the model demonstrated great skill in simulating $T_{\max }$ and $T_{\min }$ in low altitudinal regions, whereas $T_{\min }$ seems to be better reproduced than $T_{\max }$. As far as maximum temperature is concerned, it is evident that the model tends to overestimate summer maximum temperatures in coastal areas. Regarding $T_{\max }$ in high elevated regions, the model presented overestimated values all over the year in the two mountainous stations studied, namely Amiantos and Prodromos (not shown). With respect to precipitation, the model results are generally of the same magnitude as the observational data (apart from few exceptionally high daily amounts) indicating that the fundamental physics is captured by the model. In overall agreement with the results for $T_{\max }$ and $T_{\min }$, the model reproduces, to a lesser degree, $\mathrm{RR}$ in high elevation areas. According to the station records, the two stations (Amiantos and Prodromos), which are located at considerably higher elevations compared to the rest of the sites, receive the highest precipitation amounts of the region. In these cases the model performs poorly in reproducing precipitation. 

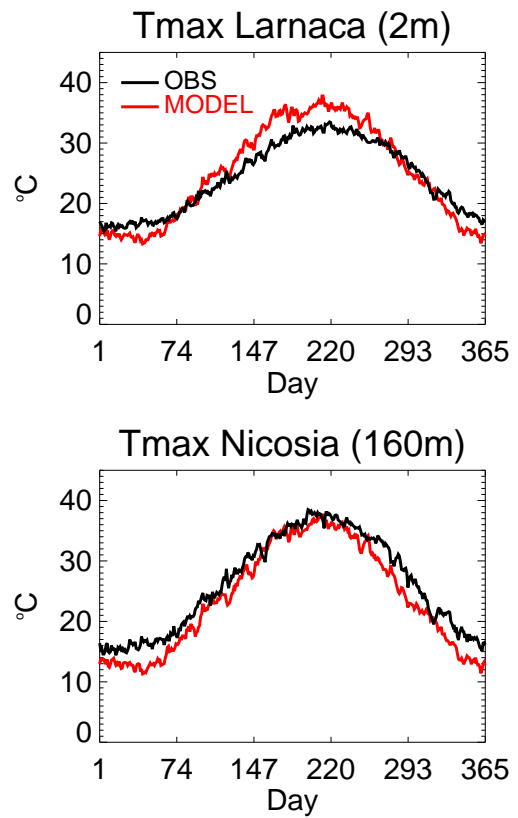

Tmax Amiantos (1397m)

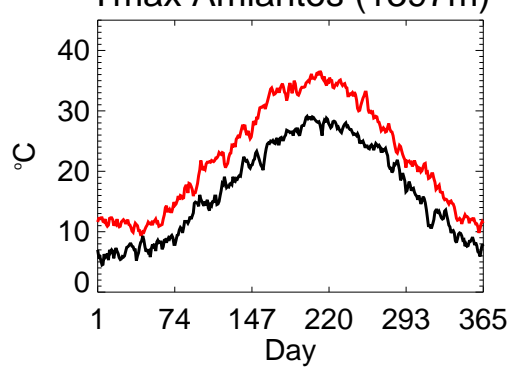

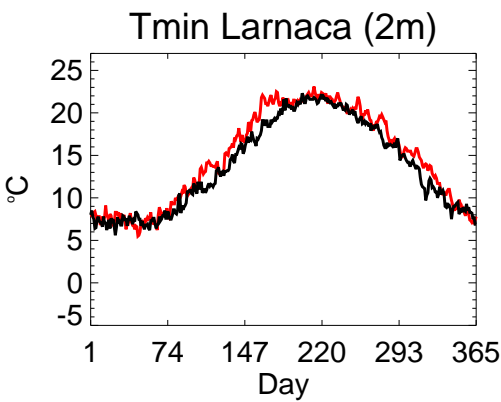
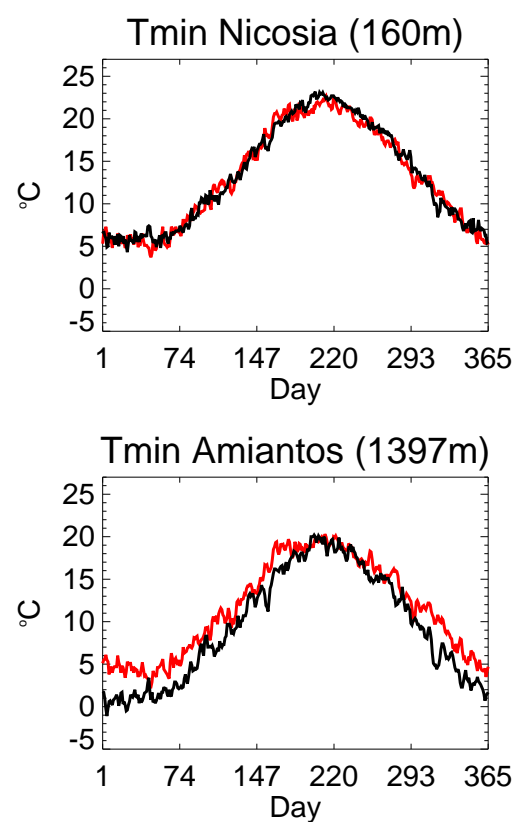
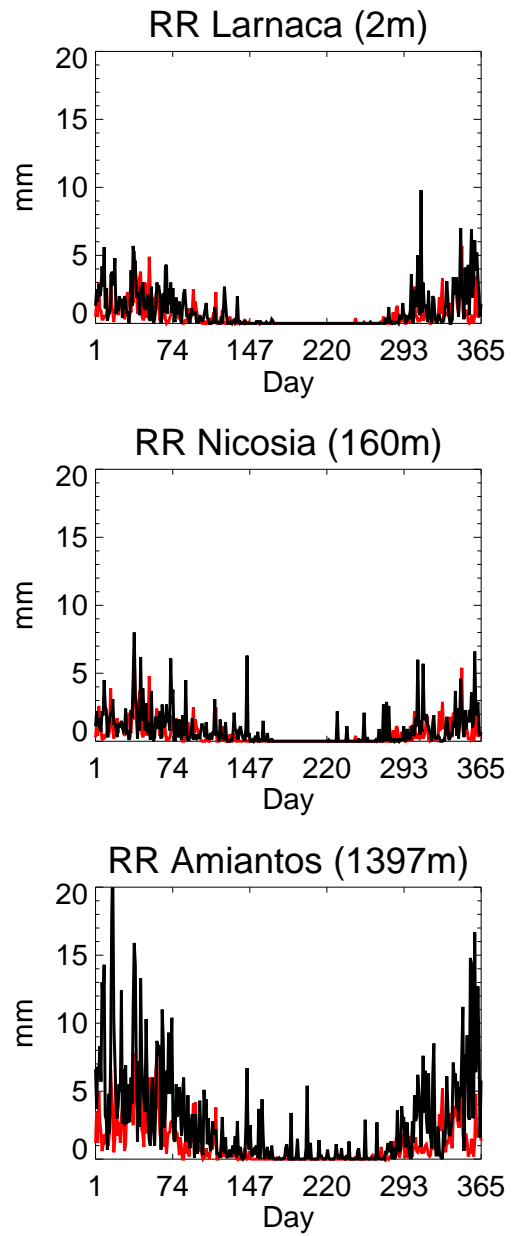

Fig. 1. Curves show the 30-year mean annual cycles of observed (black) and modelled (red) maximum (left), minimum temperature (middle) and precipitation (right) at three representative stations. Temperature is measured in ${ }^{\circ} \mathrm{C}$ and precipitation in $\mathrm{mm} / \mathrm{day}$.

The accuracy of the model was further assessed by correlation analyses undertaken between model and station observations. Statistically significant correlation coefficients exceeding 0.8 were defined for all stations and for both $T_{\max }$ and $T_{\min }$. Unfortunately, correlations among precipitation datasets did not reveal encouraging results, as in many cases coefficients were below 0.5 . An analysis of the daily differences between model and station data resulted in findings consistent with those of the seasonal cycle reproductions. In general, the model simulates better (i) $T_{\min }$ than $T_{\max }$, (ii) summer than winter temperatures and (iii) low than high altitude locations. Precipitation seems harder to reproduce, however, daily differences revealed an adequate representation by the model. Dry days were better captured by the model, although the model shows a deficiency to capture days with intense precipitation events. Some exceptional differences were detected in high altitude stations, which receive larger rainfall amounts.

\section{Future projections}

Using available daily output from the RACMO2 RCM, climatic changes in both mean (temperature, precipitation) and extremes (number of hot days, number of warm nights, drought length) were examined, with the aim to identify regions in the study area that are likely to be mostly affected by climate change.

Both future simulations, 2021-2050 and 2071-2100 (Fig. 2), indicate an increase of maximum temperature $\left(T_{\max }\right)$ on the island compared to the control run period 1961-1990, with higher increases inland and lower at the coastal areas. More specifically, for the average annual maximum temperature, the 2021-2050 simulation shows an increase of about $1.6^{\circ} \mathrm{C}$ inland, while the increase in the coastal areas and the surrounding sea is about $1.3^{\circ} \mathrm{C}$. The increase of this index for the $2071-2100$ future period is about $4.3^{\circ} \mathrm{C}$ and $3.5^{\circ} \mathrm{C}$ respectively. For the winter time period the average temperature increases by about $1.4^{\circ} \mathrm{C}$, for the first future period and by about $3.6^{\circ} \mathrm{C}$ for the second (difference of about $2.2^{\circ} \mathrm{C}$ 
Average Annual Tmax
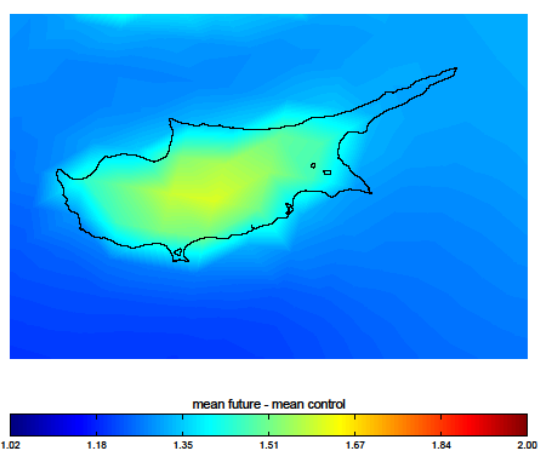

Average Winter Tmax
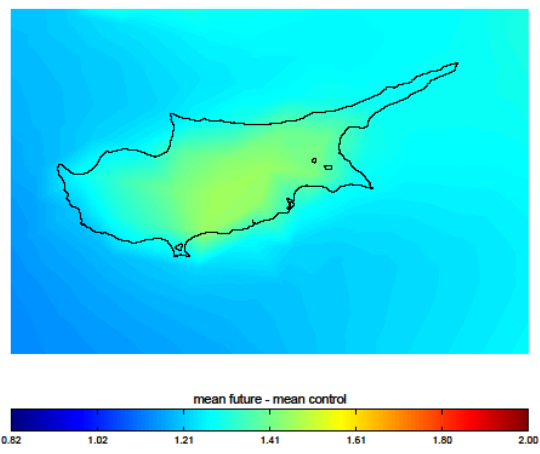

Average Summer Tmax
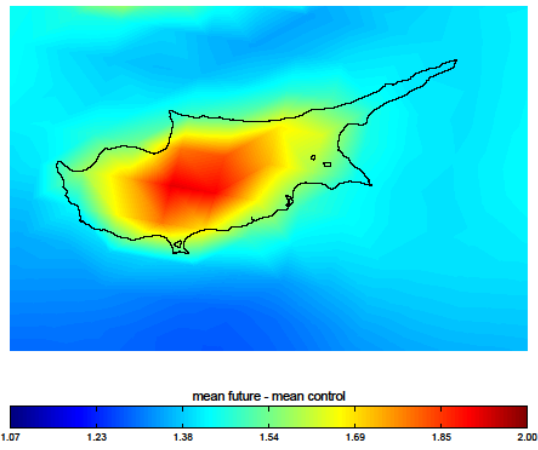

nb of heatwaves days (TMAX $>35 \mathrm{deg}$ )
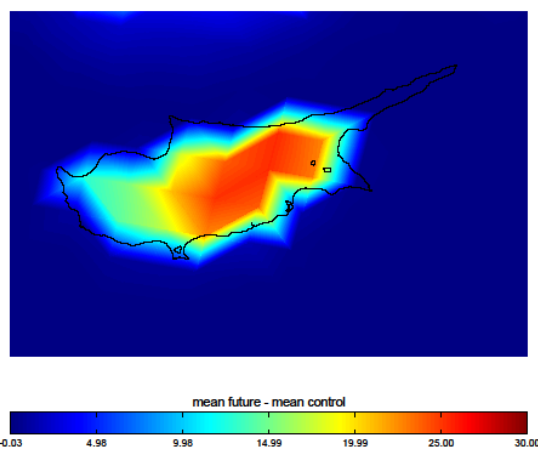

Average Annual Tmax
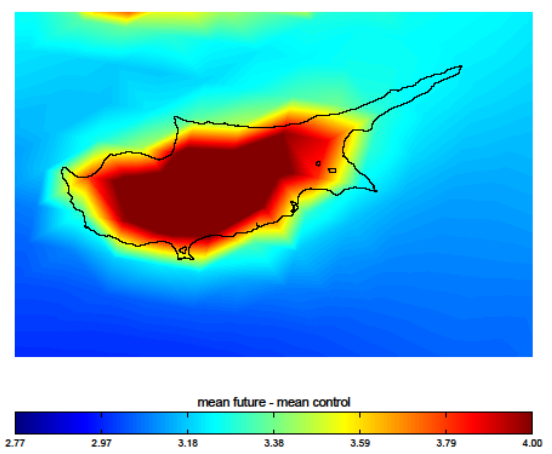

Average Winter Tmax
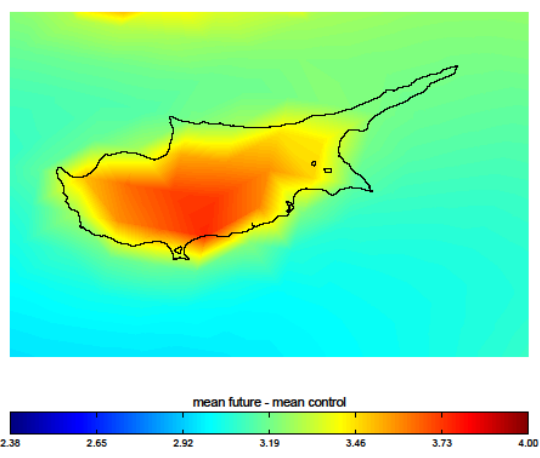

Average Summer Tmax
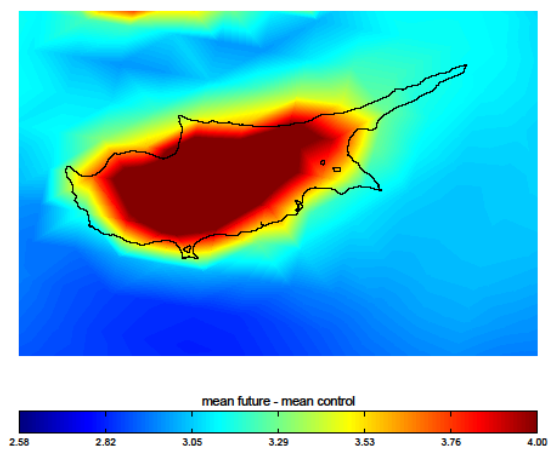

nb of heatwaves days (TMAX $>35 \mathrm{deg}$ )
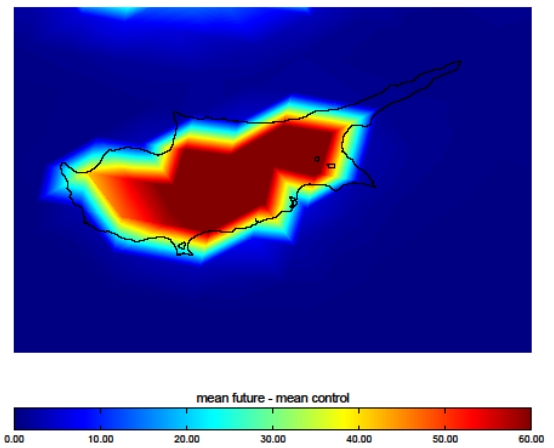

Fig. 2. Mean differences between the 2021-2050 future simulation (left), the 2071-2100 future period (right) and the control run period for the average annual $T_{\max }$, average winter $T_{\max }$, average summer $T_{\max }$, number of days with $T_{\max }>35^{\circ} \mathrm{C}$. 
among the future simulations), while for the summer period the increases are about $1.9^{\circ} \mathrm{C}$ for the first and $5^{\circ} \mathrm{C}$ for the second period (difference of about $3.1^{\circ} \mathrm{C}$ among the future simulations). The increase of the average maximum temperature mentioned above, compared to the control run period is further enhanced by the increased number of heatwave days (defined as number of days with temperatures exceeding $35^{\circ} \mathrm{C}$ ) which are simulated for the two future periods. The 2021-2050 simulation shows that there will be 25 more "heatwave" days per year, while the 2071-2100 simulation shows an increase of about 2 months. In order to estimate the magnitude increase of the above parameters in the two future simulations the average values for the control run period (1961-1990) of the annual $T_{\max }$, winter $T_{\max }$, summer $T_{\max }$, number of days with $T_{\max }>35^{\circ} \mathrm{C}$ are given below.

$$
\begin{aligned}
& \text { - Average annual } T_{\max } \sim 24^{\circ} \mathrm{C} \\
& \text { - Average winter } T_{\max } \sim 15{ }^{\circ} \mathrm{C} \\
& \text { - Average summer } T_{\max } \sim 34^{\circ} \mathrm{C} \\
& \text { - Number of days with } T_{\max }>35^{\circ} \mathrm{C} \sim 60 \text { days }
\end{aligned}
$$

Regarding minimum temperatures, the two simulations indicate a different pattern of their spatial distribution compared to the maximum ones, with increases covering almost the whole territory of the island (Fig. 3). More specifically the 2021-2050 simulation shows an increase of the average annual $T_{\min }$ of about $1.5^{\circ} \mathrm{C}$, whereas the 2071-2100 an increase of about $4{ }^{\circ} \mathrm{C}$ is noted. In both simulations the lowest increases (about $1.3^{\circ} \mathrm{C}$ for the $2021-2050$ simulation, and about $3.1^{\circ} \mathrm{C}$ for the $2071-2100$ simulation) of the average annual $T_{\min }$ are distributed in the coastal area of the island and the Northeastern part of it. As far as average winter $T_{\min }$ is concerned an increase of about $1.3^{\circ} \mathrm{C}-1.4^{\circ} \mathrm{C}$ is simulated for the 2021-2050 simulation, while the increase for the $2071-2100$ simulation is about $3.3^{\circ} \mathrm{C}$. A change of the warming pattern is projected on the average summer $T_{\min }$ with the maximum average temperatures being simulated in both cases in the mountainous area of the island (about $1.9^{\circ} \mathrm{C}$ for the 2021-2050 simulation, and about $4.3^{\circ} \mathrm{C}$ for the $2071-$ 2100 simulation), while the rest of the inland shows lower increases (of about $0.1^{\circ} \mathrm{C}$ in both simulations. Furthermore, the increase of the average annual $T_{\min }$ mentioned above is enhanced by the considerable increase of the number of tropical nights (which is defined as the number of nights with temperatures exceeding $20^{\circ} \mathrm{C}$ ). Particularly, for the 20212050 simulation the increase of the number of tropical nights is about 45 days, while the 2071-2100 simulation shows an increase of about 3 months. In order to estimate the magnitude increase of the above parameters in the two future simulations the average values for the control run period (19611990) of the annual $T_{\min }$, winter $T_{\min }$, summer $T_{\min }$, number of nights with $T_{\min }>20^{\circ} \mathrm{C}$ are given below:

- Average annual $T_{\min } \sim 15^{\circ} \mathrm{C}$
- Average winter $T_{\min } \sim 8^{\circ} \mathrm{C}$

- Average summer $T_{\min } \sim 22^{\circ} \mathrm{C}$

- Number of nights with $T_{\min }>20^{\circ} \mathrm{C} \sim 75$ days

The projected percentage changes of precipitation for the two future periods, are given in Fig. 4. In both future simulations a decrease of the average annual total rainfall is simulated. More specifically, for 2021-2050 simulation the decrease of precipitation varies from $6 \%$ to $18 \%$ depending on the area of the island, while for the 2071-2100 simulations this decrease varies from $20 \%$ to $35 \%$, compared to the control period. The precipitation changes in the two simulations for the winter total rainfall present similar spatial patterns. In winter, precipitation decreases more than the average total rainfall (about 25\% for the 2021-2050 simulation, and about $40 \%$ for the 2071-2100 simulation). This higher decrease in winter, is accompanied, only for the 2021-2050 period, by an increase of precipitation in autumn (about 35\%). For the 2071-2100 future simulation and for the autumn period the simulations show a decrease on the South-West of the island (of about 20\%) and an increase of about $10 \%$ in the NorthEast of the island. The simulated increase in autumn precipitation may be due to elevated sea surface temperatures in the region after the hot summer period together with enhanced sea breezes.

Furthermore, in both simulations an increase of the dry period with precipitation below $1 \mathrm{~mm}$ is indicated. More specifically for the 2021-2050 simulation the increase is of about $7 \%$ ( $\sim 15$ more days), while for the 2071-2100 varies between $12 \%$ ( $\sim 15$ more days) and $25 \%$ ( $\sim 1$ more month) depending on the area of the island.

\section{Summary}

The evaluation of the model against the observational data showed that simulated fields such as maximum and minimum temperature closely resemble the observed records. The simulations are poorer in regions situated at higher altitudes. As far as the estimated precipitation is concerned, the model performed generally well, despite the fact that it tended to underestimate high precipitation amounts compared to the measured data. Overall, the evaluation results are encouraging for the use of such RCM data to estimate potential effects of climate change in Cyprus.

Based on projections of future changes in temperature and precipitation, this study shows the vulnerability of Cyprus to future climate change in two 30 -year future periods. Regarding maximum temperature, in both simulations Cyprus seems to undergoes warming. The warming, depending on the season, is in the range of $1.3^{\circ} \mathrm{C}$ to $1.9^{\circ} \mathrm{C}$ for the $2021-$ 2050 simulation and $3.6^{\circ} \mathrm{C}$ to $5^{\circ} \mathrm{C}$ for the $2071-2100$ simulation. For the minimum average temperature the simulations indicate an increase of about $1.5^{\circ} \mathrm{C}$ for the $2021-2050$ 

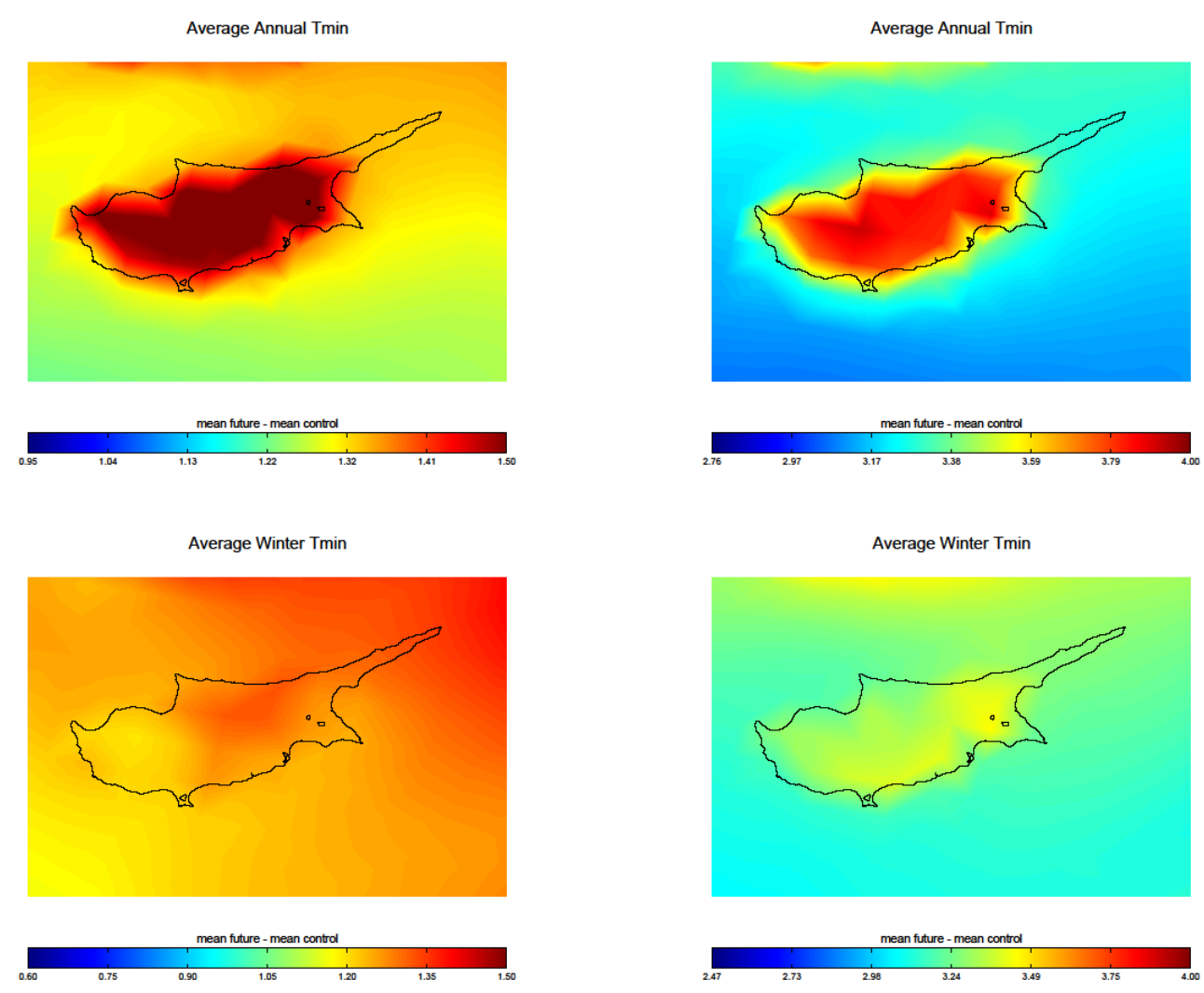

Average Summer Tmin
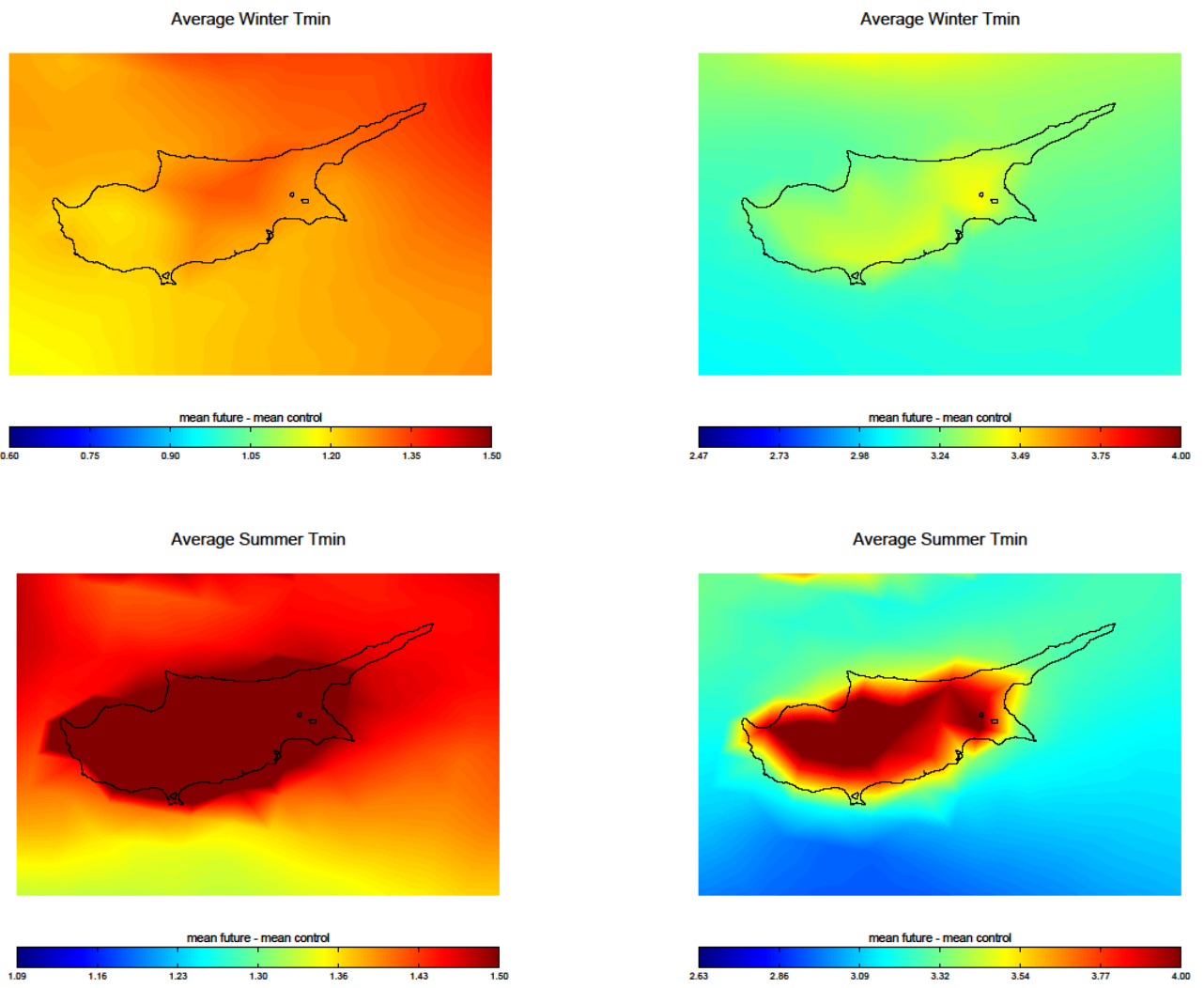

nb of tropical nights (TMIN $>20 \mathrm{deg})$
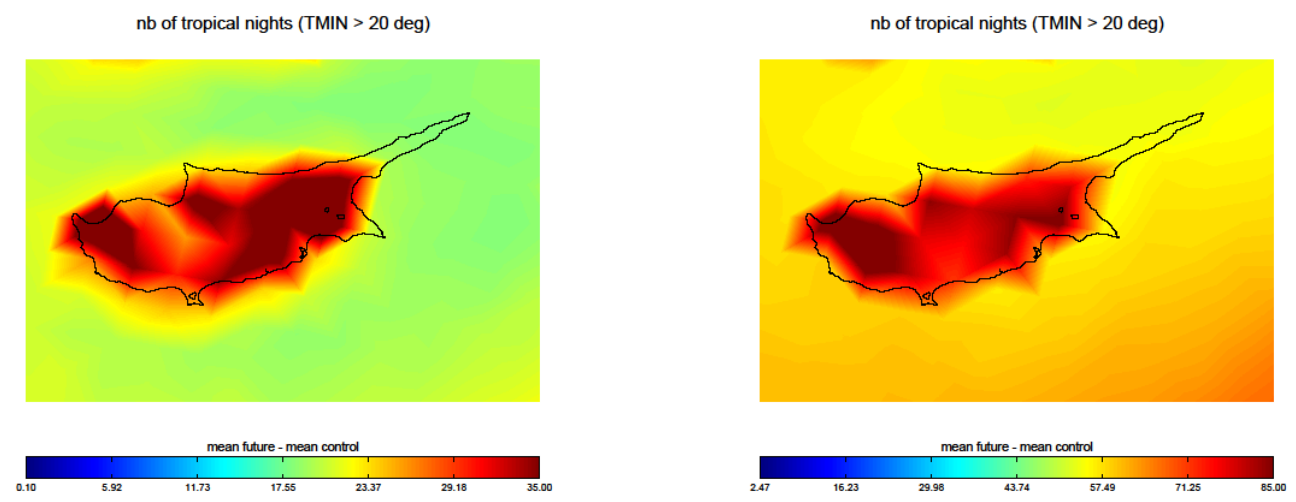

Fig. 3. Mean differences between the 2021-2050 future simulation (left), the 2071-2100 future period (right) and the control run period for the average annual $T_{\min }$, average winter $T_{\min }$, average summer $T_{\min }$, number of tropical nights with $T_{\min }>20^{\circ} \mathrm{C}$. 


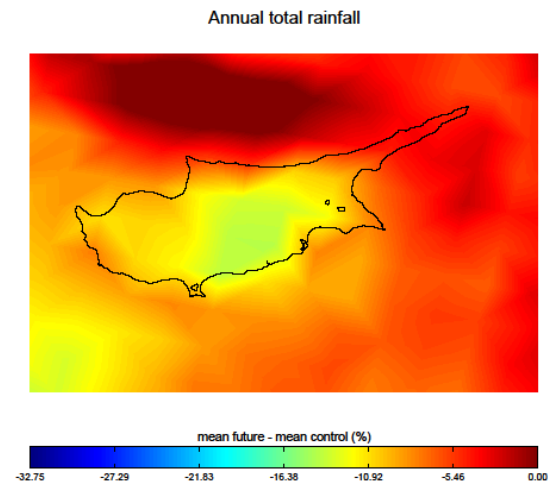

Winter total rainfall
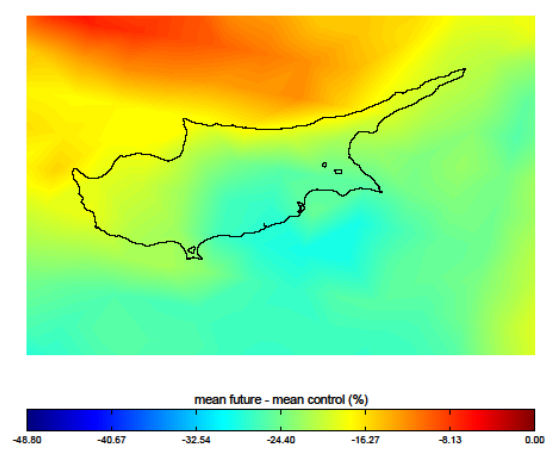

Fall total rainfall
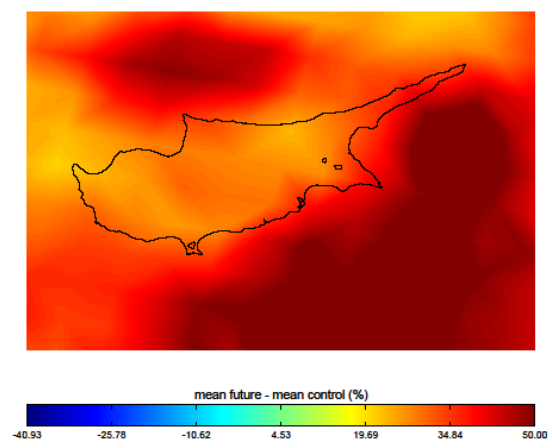

max length of dry spell $(<1 \mathrm{~mm})$
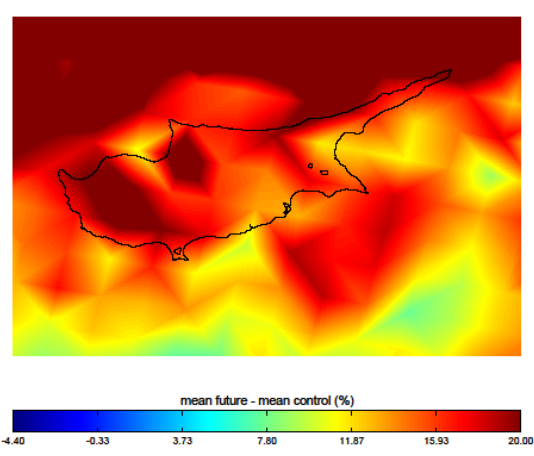

Annual total rainfall
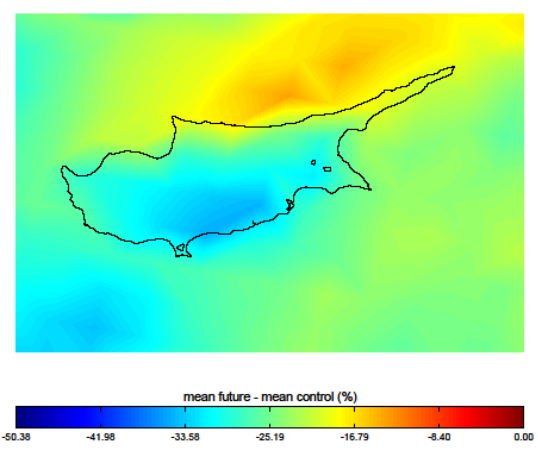

Winter total rainfall
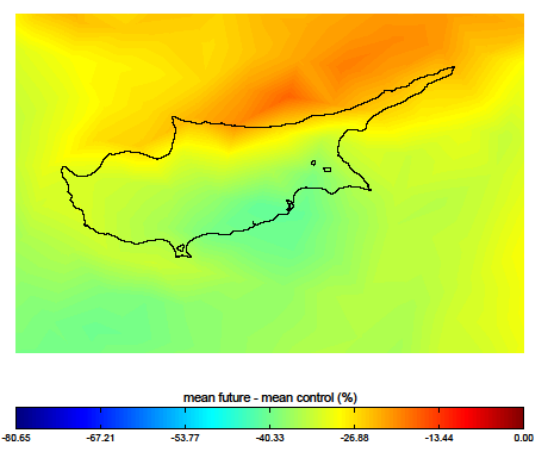

Fall total rainfall

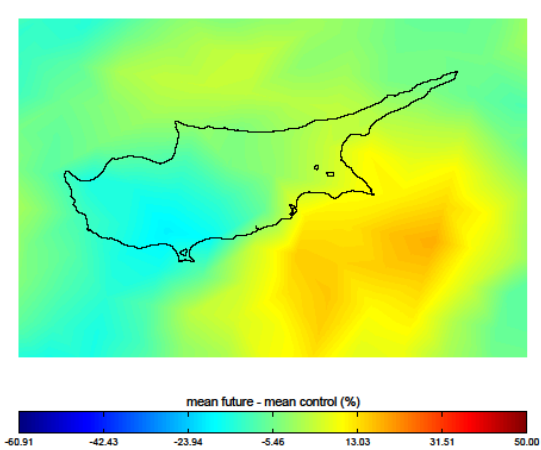

max length of dry spell $(<1 \mathrm{~mm})$
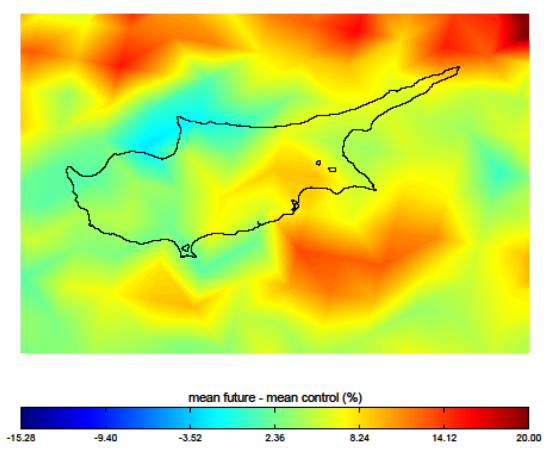

Fig. 4. Percentage differences between the 2021-2050 future period (left), the 2071-2100 future period (right) and the control run period for the annual total rainfall, winter total rainfall, autumn total rainfall and the duration of the period with precipitation under $1 \mathrm{~mm}$. 
simulation and $4{ }^{\circ} \mathrm{C}$ for $2071-2100$. The seasonal variability varies between $1.3^{\circ} \mathrm{C}$ in winter and $1.9^{\circ} \mathrm{C}$ in summer for the 2021-2050 simulation, whereas for the 2071-2100 simulation is in the range of $3.3^{\circ} \mathrm{C}$ (winter) to $4.3^{\circ} \mathrm{C}$ (summer). Finally, the future simulations indicate a drop in rainfall amounts. The sharpest decrease is evident seasonally for the 2071-2100 simulation (decrease in winter accompanied with decrease in autumn), whereas for the 2021-2050 simulation, rainfall shows a decrease in winter, but an increase in autumn. Both simulations indicate an increase in the dry period with precipitation below $1 \mathrm{~mm}$ of about 15 days for 2021-2050 and of about 15 days to 1 month for 2071-2100.

Acknowledgements. This work was part of the project CLIMA2070, supported by the Research Promotion Foundation Cyprus through its 2006 Programme "Collaboration with Distinguished Scientist Abroad". We also thank the EU FP6 ENSEMBLES project for financial support and model data provision and the Meteorological Service of Cyprus for the observational data provided. E. Kostopoulou acknowledges support from the post-doctoral Fellowship Program by the Cyprus Institute.

Edited by: S. Michaelides, K. Nicolaides, and A. Orphanou Reviewed by: two anonymous referees

\section{References}

Alcamo, J., Moreno, J. M., Novaky, B., Bindi, M., Corobov, R., Devoy, R. J. N., Giannakopoulos, C., Martin, E., Olesen, J. E., and Shvidenko, A.: Europe, in: Climate Change 2007: Impacts, Adaptation and Vulnerability, Contribution of Working Group II to the Fourth Assessment Report of the Intergovermental Panel on Climate Change, edited by: Parry, M. L., Palutikof, J. P., Van der Linden, P. J., and Hanson, C. E., Cambridge University Press, UK, 541-580, 2007.

Christensen, J. H. and Christensen, O. B.: A summary of the PRUDENCE model projections of changes in European climate by the end of this century, Climatic Change, 81, 7-30, 2007.

Christensen, J. H., Hewitson, B., Busuioc, A., Chen, A., Gao, X., Held, I., Jones, R., Kolli, R. K., Kwon, W. T., Laprise, R., Magana Rueda, V., Mearns, L., Menendez, C. G., Raisanen, J., Rinke, A., Sarr, A., and Whetton, P.: Regional Climate Projections, in: Climate Change 2007: The Physical Science Basis. Contribution of Working Group I to the Fourth Assessment Report of the Intergovernmental Panel on Climate Change, edited by: Solomon, S., Qin, D., Manning, M., Chen, Z., Marquis, M., Averyt, K. B., Tignor, M., and Miller, H. L., Cambridge University Press, Cambridge, UK and New York, NY, USA, 2007.

Déqué, M., Jones, R. G., Wild, M., Giorgi, F., Christensen, J. H., Hassell, D. C., Vidale, P. L., Rockel, B., Jacob, D., Kjellstrom, E., de Castro, M., Kucharski, F., and van den Hurk, B.: Global high resolution versus limited area model climate change scenarios over Europe: quantifying confidence level from PRUDENCE results, Clim. Dynam., 25, 653-670, 2005.
Déqué, M., Rowell, D. P., Lüthi, D., Giorgi, F., Christensen, J. H., Rockel, B., Jacob, D., Kjellström, E., de Castro, M., and van den Hurk, B.: An intercomparison of regional climate simulations for Europe: assessing uncertainties in model projections, Climatic Change, 81, 53-70, 2007.

Gao, X., Pal, J. S., and Giorgi, F.: Projected changes in mean and extreme precipitation over the Mediterranean region from high resolution double nested RCM simulations, Geophys. Res. Lett., 33, L03706, doi:10.1029/2005GL024954, 2006.

Gao, X. and Giorgi, F.: Increased aridity in the Mediterranean region under greenhouse gas forcing estimated from high resolution regional climate projections, Global Planet. Change, 62, 195-209, 2008.

Giorgi, F.: Climate change Hot-Spots, Geophys. Res. Lett., 33, L08707, doi:10.1029/2006GL025734, 2006.

Hewitt, C. D.: The ENSEMBLES Project: Providing ensemblebased predictions of climate changes and their impacts, EGGS newsletter, 13, 22-25, 2005.

Kostopoulou, E. and Jones, P. D.: Comprehensive analysis of the climate variability in the eastern Mediterranean, Part I: Map pattern classification, Int. J. Climatol., 27, 1189-1214, 2007a.

Kostopoulou, E. and Jones, P. D.: Comprehensive analysis of the climate variability in the eastern Mediterranean, part II: relationships between atmospheric circulation patterns and surface climatic elements, Int. J. Climatol., 27, 1351-1371, 2007 b.

Lenderink, G., van Ulden, A., van den Hurk, B., and Keller, F.: A study on combining global and regional climate model results for generating climate scenarios of temperature and precipitation for The Netherlands, Clim. Dynam., 29(2-3), 157-176, 2007.

Meehl, G. A., Stocker, T. F., Collins, W. D., Friedlingstein, P., Gaye, A. T., Gregory, J. M., Kitoh, A., Knutti, R., Murphy, J. M., Noda, A., Raper, S. C. B., Watterson, I. G., Weaver, A. J., and Zhao, Z. C.: Global Climate Projections, in: Climate Change 2007: The Physical Science Basis, Contribution of Working Group I to the Fourth Assessment Report of the Intergovernmental Panel on Climate Change, edited by: Solomon, S., Qin, D., Manning, M., Chen, Z., Marquis, M., Averyt, K. B., Tignor, M., and Miller, H. L., Cambridge University Press, Cambridge, UK and New York, NY, USA, 2007.

Pashiardis, S.: Trends of precipitation in Cyprus rainfall analysis for agricultural planning, UN Food and Agriculture Organization (FAO), Climagri Workshop, on Development of a regional network on climate change and agriculture for the countries in the Mediterranean region, FAO's headquarters, Rome, Italy, 2002.

Pinto, J. G., Ulbrich, U., and Speth, P.:. The variability of Cyclonic activity in the Mediterranean area in the last 40 years and its impact on precipitation, Mediterranean Storms, Proceedings Plinius Conference, 2001. 